\title{
卜
}

\section{Chemorheology for Natural Rubber Vulcanized in Swollen State}

by

Kyung-Do SuH, Hidetoshi Oikawa, and Kenkichi Murakami

Chemical Research Institute of Non-Aqueous Solutions,

Tohoku University, Katahira 2-chome, Sendai, Miyagi 980

Natural rubber vulcanized in swollen state (SC-sample) is expected to have different topology of chain network compared with the sample vulcanized in dry state (NR-sample, . These two types of samples were employed to investigate the effect of the physical flow on chemical stress relaxation. SC-samples showed much lower values of Mooney-Rivlin's $C_{2}$ term than those for NR-samples, and broke at relatively small strains before the hardening due to crystallization occurred. The unique stress-strain behavior of the SCsamples, especially at the low network chain density, may be attributable to the sparseness of inextricable chain entanglement. The stress for SC-samples decreased exponentially with time and the rate of stress decay at short times was lower than that for NR-samples on chemical stress relaxation tests. Futhermore, the stress decreased very rapidly at the last stage of degradation. It is suggested that the most important difference between SC and NR-samples lies in the degree of trapped entanglement of the network chain. Such entanglements present amply in NR-samples give rise to a physical flow in addition to the chemical stress relaxation.

\section{溶液加硫天然ゴムのケモレオロジー}

\author{
徐 卿道 - 及川 英俊 - 村上 謙吉*
}

（原稿受理：1985年 4 月 1 日）

\section{1. 緒言}

網目構造を持つ高分子物質の劣化現象を応力緩和法を用いて追 跡する際, 従来のゴム弾性理論に基づく化学レオロジーでは, 応 力の減少が劣化による試料の網目密度変化と直接刘応すると仮定 している. しかしながら, そのゴム弾性理諭が1970年代後半より 見直されて扣り，また実際の加硫ゴムが複雑な不均一網目構造で あることを考只わせると, 応力の減少と網目密度の変化との間 に単純な比例関係が成り立つという従来の考方方には疑問が残る. われわれはこれまで, 劣化を受けた加硫ゴムの応力一歪举動を Mooney-Rivlinプロットによって解析した，その結果，網目中に

* 東北大学非水溶液化学研究所 $\mathbf{T} 980$ 仙台市片平 2 丁目 $1-1$
存在するからみ合いのような二次的結合とか網目鎖間の相互作用 などが力学物性に及ぼす影響は, 未劣化加硫天然ゴムの場合とは かなり異なることがわかっだ1).

そこで，今回はこの点を更に明確にするために，ゴム分子鎖の 凝集状態がかなり異なっていると考えられる溶液状態で加硫を行 い, 通常加硫試料の力学物性と比較することによって, 網目構造 上の違いが化学応力緩和に及ぼす影響を詳細に検討した。

\section{2. 実}

\section{験}

溶液加硫試料の調製は次の方法で行った．未加硫天然ゴムに所 定の量のデカリンとジクミルペルオキシド (DCP) を加えた後, よく摫拌して均一な溶液にする。㹂找時に生じた気泡は真空減圧 
Table I. Preparations of samples vulcanized in swollen state and the initial network chain density, $n_{\mathrm{sw}}(0)$.

\begin{tabular}{lcccc}
\hline $\begin{array}{c}\text { Sample } \\
\text { No. }\end{array}$ & $\begin{array}{c}\text { Decalin*1 } \\
(\mathrm{ml})\end{array}$ & $\begin{array}{c}\text { DCP*2 } \\
(\mathrm{g})\end{array}$ & $\begin{array}{c}\text { Curing time } \\
(\mathrm{hr})\end{array}$ & $\begin{array}{c}10 \times n_{\mathrm{sw}}(0) * 3 / \\
\mathrm{moldm}^{-3}\end{array}$ \\
\hline SC-1 & 100 & 2 & 2 & 0.056 \\
SC-2 & 100 & 2.5 & 2 & 0.077 \\
SC-3 & 100 & 3 & 2 & 0.141 \\
SC-4 & 100 & 3 & 3 & 0.188 \\
SC-5 & 90 & 2 & 3 & 0.216 \\
SC-6 & 90 & 2.5 & 3 & 0.227 \\
SC-7 & 90 & 3 & 3 & 0.250 \\
SC-8 & 80 & 3 & 3 & 0.283 \\
SC-9 & 80 & 5 & 3 & 0.427 \\
SC-10 & 70 & 3 & 3 & 0.442 \\
SC-11 & 70 & 5 & 3 & 0.458 \\
SC-12 & 60 & 5 & 2 & 0.548 \\
SC-13 & 60 & 5 & 3 & 0.667 \\
SC-14 & 40 & 5 & 3 & 1.475 \\
\hline
\end{tabular}

*1 $\mathrm{ml} / 10 \mathrm{~g}$ (natural rubber)

*2 $\mathrm{g} / 100 \mathrm{~g}$ (natural rubber)

*3 determined by using the swelling method.

下で除去する，脱気の終ったゴムーデカリン溶液の所定量をシャ ーレに入れ， $418 \mathrm{~K}$ の窒素雾囲気中で加硫した. 加硫試料は 24 時 間ベンゼン中で抽出操作を行ってデカリンを除去した後, メタノ 一ル中で注意樑く収縮させた。 その後, 更に24時間熱アセトンで 抽出を行い, 真空乾燥した. Table 1 に本研究に用いた溶液加硫 試料の調製条件と初期網目密度を示す.

一方, 通常加硫試料は未加硫ゴムに DCP をロールミルで混ぜ, ホットプレスで $418 \mathrm{~K}, 20 \mathrm{MPa}$ の下で所定時間加硫することによ って調製した. その後, 加硫試料は48時間熱アセトン抽出を行い, 真空乾燥した. 通常加硫試料の調製条件と初期網目密度を Table 2 亿示す.

調製試料の初期網目密度， $n_{\mathrm{sw}}$ は試料をトルエン中（303K） に浸漬して膨潤度を求め, Flory-Rehner の式地から算出した。

応力-歪挙動の測定は島津製オートグラフ DSC-100 型を用い， 室温, 延伸速度 $50 \mathrm{~mm} \mathrm{~min} \mathrm{mi}^{-1}$ で行った.

Table II. Preparations of samples vulcanized in dry state and the initial network chain density, $n_{\mathrm{sw}}(0)$.

\begin{tabular}{cccc}
\hline $\begin{array}{c}\text { Sample } \\
\text { No. }\end{array}$ & DCP*1 & $\begin{array}{c}\text { Curing time*2 } \\
(\mathrm{min})\end{array}$ & $10 \times n_{\mathrm{sw}}(0) / \mathrm{moldm}^{-3}$ \\
\hline NR-1 & 2 & 5 & 0.056 \\
NR-2 & 2 & 7.5 & 0.084 \\
NR-3 & 2 & 10 & 0.179 \\
NR-4 & 2 & 15 & 0.224 \\
NR-5 & 2 & 20 & 0.285 \\
NR-6 & 3 & 15 & 0.462 \\
\hline
\end{tabular}

*1 Dicumeneperoxide.

*2 $418 \mathrm{~K}, 20 \mathrm{MPa}$.

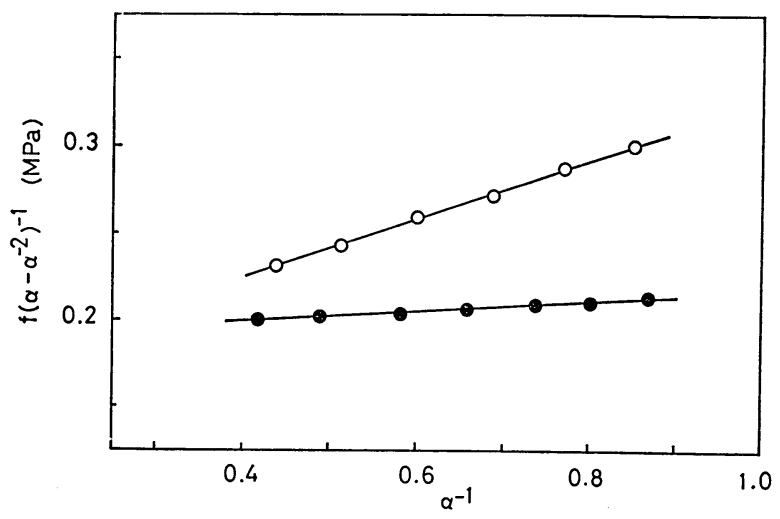

Fig. 1 Mooney-Rivlin Plots for dry-state cured natural rubber (NR-sample) and solution-cured natural rubber (SC-sample) : O, NR-6;, , SC-11.

\section{3. 結果および考察}

Fig. 1は，ほぼ同じ網目密度を持つ溶液加硫試料と通常加硫試 料の Mooney-Rivlin プロットである. ここで， $\alpha$ は伸長比， $f$ は伸長応力を示す. 溶液加硫試料の $2 C_{2}$ の值（直線の傾き）は通 常加硫試料の約 $1 / 10$ 程度で, ほぼ零に近い值を取っている。この $C_{2}$ 項に刘しては，これまでさまざまな議論が行われている。す なわち, 高分子の粘性や極性と強く関係し, 延伸速度, 温度など の測定条件によっても変わる值であると言われている22,4). 最近， われわれは劣化網目への Mooney-Rivlin プロットの適用により， $C_{2}$ 項が緩和強度を表すパラメーターであることを示唆した．いず れにせよ，この $2 C_{2}$ 值の大きな差が両試料の網目構造上の違いを 反映していることは間違いない.

Fig. 2 は, 種々の架橋度を持つ溶液加硫試料の応力一歪挙動を 示す。いずれの試料に扔いても，通常加硫試料に見られる高延伸 側の応力の立ち上がり現象が全く現れない，溶液加硫試料はある 程度分子鎖が広がっている溶液状態で架橋されるとい5事と, 本 実験でのゴムーデカリン溶液の濃度から言って, 通常加硫試料に 比べからみ合いのような二次的結合点が少なく，網目はほとんど 化学的架橋によって形成されるものと考穴られる. 通常加硫試料 に招いて現れる応力一歪曲線に括ける立ち上がり現象は, ゴムの 結晶化と非常に密接な関係があることが知られている．溶液加硫

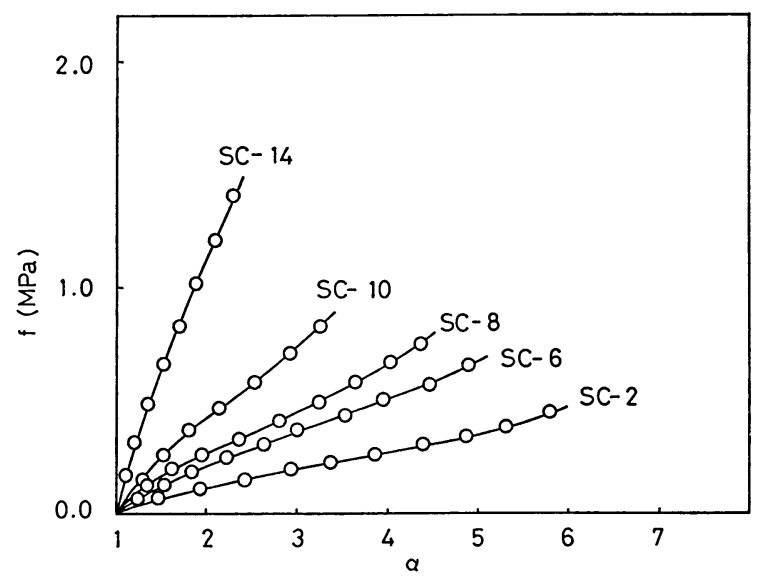

Fig. 2 Stress-strain behaviors for SC-samples. 


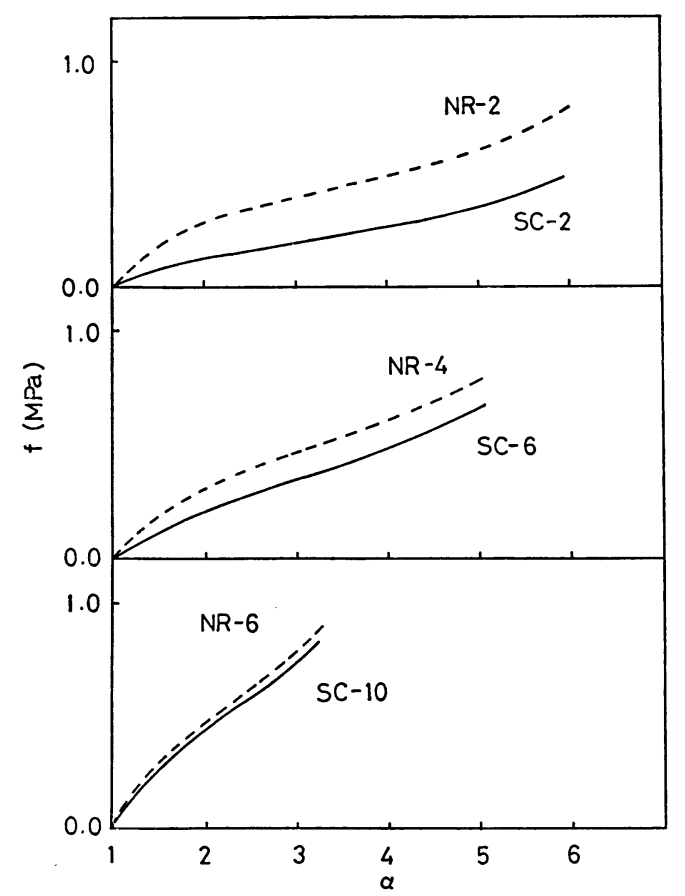

Fig. 3 Comparison of stress-strain behaviors for NRsamples and those for SC-samples with the same network chain density.

試料の場合, このような立ち上がり現象が現れないというのは, 結局結晶化し難いことを意味するるのであるが, これは先にも述 ベたように網目がほとんど架橋点によって形成されているので, 分子鎖の配向が生じにくく，また化学的架橋点が結晶化を阻害す るものと考兄られる. 更に, 溶液状態で広がった網目鎖の形態は 架橋後, デカリンが抽出された後, 元の平衡状態に完全にもどっ ているとは考方難く, 通常加硫試料と比較して比較的低丕であっ ても分子鎖は伸びきり，破断してしまうものと考学られる.いず れにしても両試料の最大の違いは, トラップされたからみ合い結 合数が, 全体の架橋点に占める割合の違いによるものと考兄られ る.この点については以下で更に議論する.

次に両試料の応力-歪挙動を, ほぼ同じ網目密度を持つ試料別 に比較したのが Fig. 3 である.ここで点線が通常加硫試料, 実 線が溶液加硫試料の応力一歪曲線を示す. 溶液加硫試料について は, 破断に至る全歪範囲が示してあるが, 通常加硫試料では更に 高伸長度に至るまで破断が生じない. 両試料の応力-歪挙動の傾 向を見ると, 低架橋度の試料ほど差が大きくなっている. このよ 5 に低架橋試料の場合, 両試料の膨潤網目密度が注涪同じである にもかかわらず, 応力-歪举動に差があるのは, 低架橋度の通常 加硫試料に多数存在するトラップされたからみ合いが, 平衡状態 ではすべて捕えられないためと考えられる，一方，架橋度が高く なると, 両試料の応力一歪挙動はかなりよく一致している.これ は架橋度が増加し化学的架橋点の数が増加すると, トラップされ たからみ合いによる架橋点の数は相対的に減少し, 化学的架橋点 で網目がほ潼成されているためである。

以上の結果より, 溶液加硫試料は通常加硫試料に比べ, 網目中 にからみ合いのような二次的架橋点がかなり少ないことが予想さ れる。

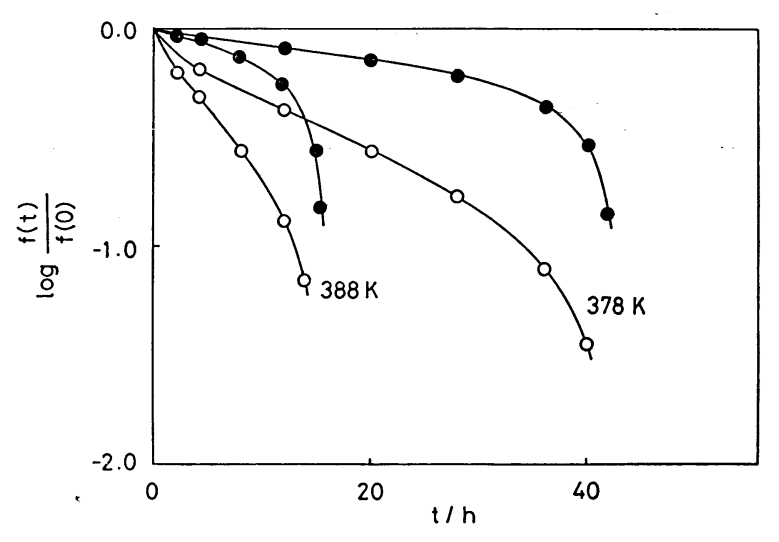

Fig. 4 Chemical stress relaxation for NR-sample and SC-sample degraded at 378 and $388 \mathrm{~K}$ in air : ○, NR-4; •, SC-6.

そこで,このような網目構造上の違いが実際の化学応力緩和に 及汸す影響を調べるため，ほぼ同じ架橋度を持つ両試料の化学応 力緩和を測定し比較したのが Fig. 4 である. 両試料の応力緩和 曲線を比較してみると, 溶液加硫試料の場合は通常加硫試料に見 られる延伸初期での急激な応力の減少が見られないが，最終段階 で応力は急激に減少し，この減少率は通常加硫試料のそれよりは るかに大きいことがわかる，このような大きな差は，これまでの 結果からも明らかなように, 溶液加硫試料の網目中には物理的な 流動を引き起こしやすい欠陷が少ないためであると考兄られる。 ただし, 溶液加硫試料の最終段階での急激な応力減少は, 劣化に よる網目の破壊のために現れるものと見なした方が正しく，その 辺での応力減少率で網目全体の構造変化を予測するのは難しい. ここで, 最終段階に至るまでの応力減少の傾向を見ると, 溶液加 硫試料の方が通常加硫試料より，よい直線関係があることが明ら かである．すなわち，溶液加硫試料の方がより典型的な Maxwell 型緩和曲線を示す。一方, 通常加硫試料の場合は延伸初期に急激 な応力の低下が見られ, 直線から外れる. しかしながら, 大体近 似的な Maxwell 型緩和曲線と見なしてょかろう。これらの直線

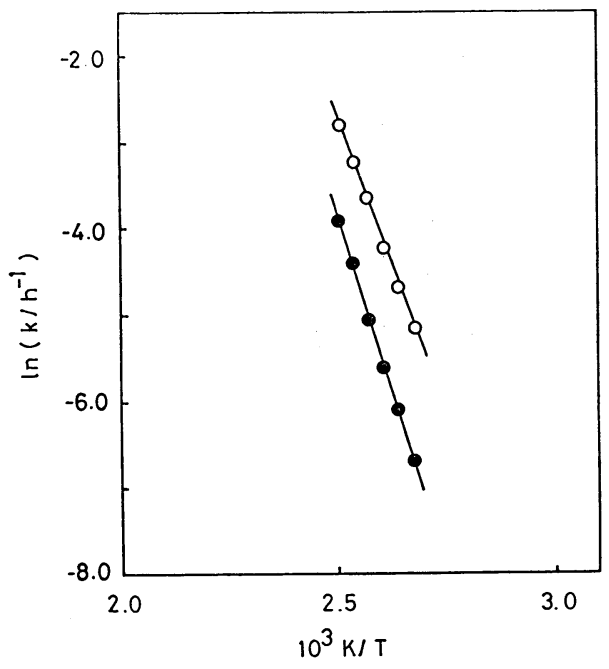

Fig. 5 Arrhenius plots for the degradation of NR-sample and $\mathrm{SC}$-sample in air :

$\bigcirc$, NR-sample ; $\bullet$, SC-sample. 
の傾きより見掛け上の速度定数 $k$ を求め, アレニウス型プロット を行 $う$ Fig. 5 のようになる. Fig. 5 より求めた通常加硫試料 と溶液加硫試料の酸化切断反応の見掛けの活性化エネルギー $E_{\mathrm{a}}$ は，それぞれ $118.4,136.4 \mathrm{kJmol}^{-1}$ であった. 通常の加硫天然 ゴムの場合, $E_{\mathrm{a}}$ の值が大体 $125 \pm 8 \mathrm{kJmol}^{-1}$ であることから 両試料の $E_{\mathrm{a}}$ の值は実験誤差の範囲内でほぼ一致するように見ら れるが, 通常加硫試料中の物理的流動要素が化学応力緩和に及ぼ す影響などを考虑すると, 通常加硫試料の $E_{\mathrm{a}}$ が若干小さい值で あることは妥当とも考えられる。 この点は今後の検討課題である. 以上, 溶液加硫試料の力学物性を通常加硫試料のそれと比較検 討した結果, 網目構造上の違いが力学物性扣よび化学応力緩和曲 線に大きな影響を及ぼしていることが明らかになった，今後は， 溶液加硫試料の力学物性を更に詳しく調べ, その網目構造との関
連性について検討を加える予定である。

（1984年10月26日第32回レオロジー討論会にて発表）

文

\section{献}

1) 徐卿道, 及川英俊, 村上謙吉, 日本レオロジー学会誌, 12, 104 (1984).

2) Flory, P.J., and J. Rehner, Jr., J. Chem. Phys., 11, 521 (1943).

3) Kastner, S., Polymer, 20, 1327 (1979).

4) Treloar, L.R.G., "The Physics of Rubber Elasticity", 3rd ed., Clarendon Press, Oxford (1975).

5）村上謙吉, “高分子の化学レオロジー”, 朝倉書店 (1974). 